\title{
Large $\mathrm{NaCl}$-effect on the Decomposition Rate of Chlorate lons in $\mathrm{HCl}$-containing Brine Solutions and Its Consequences for the Chlor-alkali Industry
}

\author{
Alexandra Jakab-Nácsa1', Dávid Stomp¹, László Farkas¹, George Kaptay²,3,4* \\ 1 Wanhua-Borsodchem, H-3700 Kazincbarcika, 1 Bolyai tér, Hungary \\ 2 Bay Zoltan Ltd. for Applied Research, H-3519 Miskolc, 2 Iglói út, Hungary \\ ${ }^{3}$ Department of Nanotechnology, Faculty of Materials Science and Engineering, University of Miskolc, H-3515 Miskolc, \\ Egyetemváros, P. O. B. 21, Hungary \\ ${ }^{4}$ MTA-ME Materials Science Research Group, H-3515 Miskolc, Egyetemváros, P. O. B. 21, Hungary \\ * Corresponding author, e-mail: kaptay@hotmail.com
}

Received: 03 July 2019, Accepted: 28 January 2020, Published online: 19 November 2020

\begin{abstract}
The decomposition rate of chlorate $\left(\mathrm{NaClO}_{3}\right)$ in aqueous solutions (brines) containing initially $6: 1 \mathrm{~mol} / \mathrm{mol} \mathrm{HCl}: \mathrm{NaClO}_{3}$ is studied at $90^{\circ} \mathrm{C}$ at various $\mathrm{NaCl}$ contents experimentally. A strong positive effect of $\mathrm{NaCl}$ addition is shown on the decomposition rate of chlorate. It is found more reasonable in the chlor-alkali industry first to saturate the brine by sodium chloride and only then to eliminate from it the chlorate by adding $\mathrm{HCl}$ (before the solution is transferred into the electrolysis cell to be protected from the chlorate ions).
\end{abstract}

\section{Keywords}

brine solution, chlorate decomposition rate, $\mathrm{HCl}$, effect of $\mathrm{NaCl}$

\section{Introduction}

Unwanted chlorate ions form as a side-product in chloralkali membrane electrolysis cells [1-3]. Therefore, reduction and elimination of chlorate from brines is of high industrial importance [4-9]. For this reason many papers have been devoted to study chlorate-chloride reactions [10-17]. The chlorate content of the brine should be kept below an acceptable level, as its presence is detrimental for the membrane in the electrolytic cell. This is possible only if the chlorate is decomposed /eliminated/ reduced in each production cycle.

One of the ways to decompose chlorate dissolved in brine is to add acids to it, such as $\mathrm{HCl}$. In this case, the following two major chemical reactions take place [18-22]:

$$
\begin{aligned}
& \mathrm{NaClO}_{3}+2 \mathrm{HCl}=\mathrm{ClO}_{2}+0.5 \mathrm{Cl}_{2}+\mathrm{NaCl}+\mathrm{H}_{2} \mathrm{O}, \\
& \mathrm{NaClO}_{3}+6 \mathrm{HCl}=3 \mathrm{Cl}_{2}+\mathrm{NaCl}+3 \mathrm{H}_{2} \mathrm{O} .
\end{aligned}
$$

The relative rates of the two parallel reactions (Eqs. (1) and (2)) depend on the $\mathrm{HCl}: \mathrm{NaClO}_{3}$ mole ratio, on the $\mathrm{pH}$ of the solution, on temperature and on the salt $(\mathrm{NaCl})$ content of brine. Chlorine dioxide is a strong oxidizer, and this property can be used in different industries [23-25].
For the same reason chloride dioxide is toxic [26, 27], and thus for safety reasons its formation in the chlor-alkali industry should be kept to minimum. This is achieved with applying high $\mathrm{HCl}: \mathrm{NaClO}_{3}$ molar ratios, as follows from the stoichiometries of reactions (Eqs. (1) and (2)).

It is more correct to write reaction (Eq. (2)) in a partly ionic form, as some of the components of this reaction are highly dissociated in water:

$\mathrm{ClO}_{3}^{-}+6 \mathrm{H}^{+}+5 \mathrm{Cl}^{-}=3 \mathrm{Cl}_{2}+3 \mathrm{H}_{2} \mathrm{O}$.

This ionic form of the chemical reaction was used also to explain kinetic measurements at both laboratory [18] and industrial [20] scales. However, in these publications $[18,20]$ experimental details and primary experimental results are not provided in sufficient detail. The experimental findings of Dotson are presented only in the form of the following semi-empirical kinetic equation [18]:

$$
-\frac{d\left[\mathrm{ClO}_{3}^{-}\right]}{d t}=
$$

$$
1.83 \times 10^{18} \times \exp \left(-\frac{35056}{R T}\right) \times \exp \left(\left[\mathrm{Cl}^{-}\right]\right) \times\left[\mathrm{ClO}_{3}^{-}\right] \times\left[\mathrm{H}^{+}\right]^{2},
$$


where $[\mathrm{X}]$ is the concentration of component $\mathrm{X}$ in brine in g-mol/litre, $T$ is absolute temperature in $K$ and $t$ is time in minutes. Eq. (4) is valid in the following parameter ranges [18]: (0 ... 4.4) $\mathrm{mol} /$ litre $\mathrm{NaCl}$; $(1$.. 18) $\mathrm{mol} / \mathrm{mol}$ $\mathrm{HCl}: \mathrm{ClO}_{3}^{-}$and $(70 \ldots 105){ }^{\circ} \mathrm{C}=(343 \ldots 378) \mathrm{K}$. However, it is not clear how many experimental points are behind Eq. (4) and how well Eq. (4) reproduces those experimental results (the primary experimental data are not available nor in tabular, neither in graphical format in [18]).

In this work the findings of Dotson will be checked by careful experiments, providing all primary experimental data. In this study the molar ratio of $\mathrm{HCl}: \mathrm{ClO}_{3}^{-}$will be fixed at $6: 1$, i.e. at the stoichiometry of Eqs. (2) and (3), and temperature will be kept at a constant value of $90^{\circ} \mathrm{C}=363 \mathrm{~K}$. The goal of the present paper is to study the salt effect at high salt content-range on the rate of decomposition of the chlorate.

In addition to scientific interest, this question is of high interest for the chlor-alkali industry. In this industry chlorate is usually decomposed right after electrolysis (see in Fig. 1(a)), which is a clever choice if the rate of chlorate decomposition decreases with increasing the $\mathrm{NaCl}$ content. However, Fig. 1(b) is also possible (see Fig. 1), when chlorate is decomposed after the brine is re-saturated by the salt and right before it is transported for electrolysis, which is a clever choice if the rate of chlorate decomposition increases with increasing the $\mathrm{NaCl}$

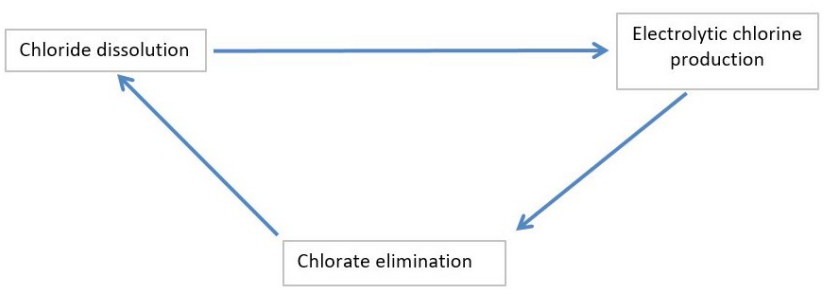

(a)

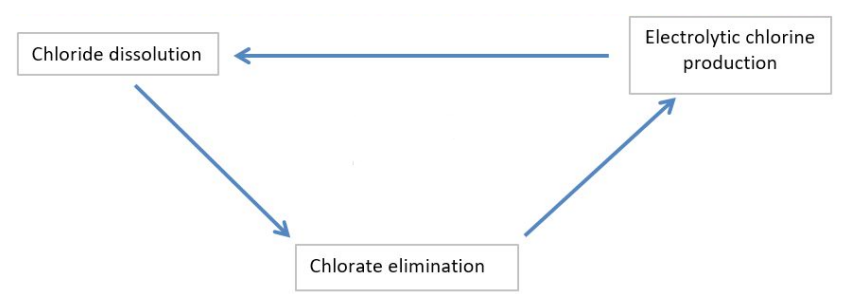

(b)

Fig. 1 Schematic of the chlor-alkali process showing only the three major processes involved. According to part (a) the chlorate is eliminated right after the electrolysis, i.e. when the brine contains the lowest amount of $\mathrm{NaCl}$, while according to part (b) the chlorate is eliminated right after the re-saturation by $\mathrm{NaCl}$, i.e. when the brine contains the highest amount of $\mathrm{NaCl}$ content. By the end of this paper it will be clear which of the parts of Fig. 1 is more preferable. It will be shown that the results of Dotson [18] and the patent based on it [20] are basically correct. However, some further details will be clarified in this paper.

\section{Experiments}

The schematic of the apparatus used to study the decomposition rate of sodium chlorate according to reactions (Eqs. (2) and (3)) is shown in Fig. 2. The aqueous solutions containing the controlled amounts of sodium chlorate and sodium chloride are kept in a double-walled beaker. Temperature is established at $90^{\circ} \mathrm{C}$ using heating water and is monitored during the experiment. Temperature variations during all experiments are within $\pm 0.5^{\circ} \mathrm{C}$. Nitrogen gas is let $2 \mathrm{~cm}$ below the surface of the solution with a constant flow rate of $11 \mathrm{~L} / \mathrm{h}$. The bottom of the solution is mixed by a magnetic mixer with a rotation speed of $400 \mathrm{rpm}$ (= rotation per minute). When steady state is established from point of view of solution flow, nitrogen flow and temperature, $\mathrm{HCl}$ is added in the amount of $6: 1$ (mol:mol) $\mathrm{HCl}: \mathrm{NaClO}_{3}$. The escaping nitrogen gas containing some chlorine gas according to reactions (Eqs. (2) and (3)) is bubbled through a $\mathrm{NaOH}$ solution. The moment when the $\mathrm{HCl}$ acid is added to the solution is taken as time zero for the reaction (it takes less than half a minute to add all the acid to the solution). Time to time a small sample is taken from the solution through the "acid inlet" neck (see Fig. 2). Each such sample is subdivided into two sub-samples and is analyzed for its chlorate content by iodo-metric titration. The two sub-samples are analyzed independently and the average analytical result is accepted if the difference between them is smaller than 5 rel $\%$.

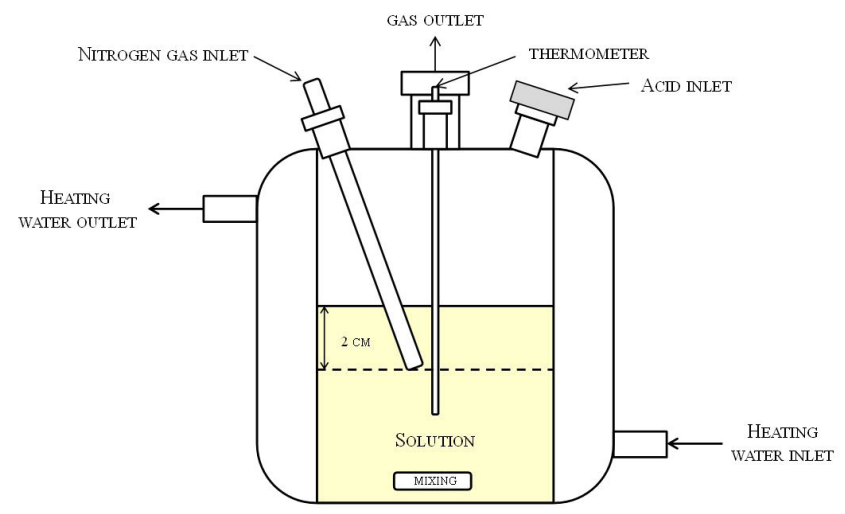

Fig. 2 Schematic of the experimental setup to study the decomposition rate of chlorate according to reactions (Eqs. (2) and (3)) 


\section{Experimental results}

\subsection{Preliminary experimental results}

First the importance of the presence of $\mathrm{HCl}$ was checked. For this, a blank experiment was run with zero amount of $\mathrm{HCl}$ under all other parameters kept constant. No decomposition of the chlorate was found in absence of $\mathrm{HCl}$ within 60 minutes at $90^{\circ} \mathrm{C}$ (see the $0-0$ point in Fig. 3). It means that for the decomposition of chlorate some acid is indeed needed as expected from reactions (Eqs. (1) and (2)).

Second, in the presence of $\mathrm{HCl}$ the formation of a chlorine gas was confirmed in agreement with reactions (Eqs. (2) and (3)) by observing during the reaction the light-green color-change of both the solution and the gas above it.

Third, the importance of the nitrogen flow was checked in several experiments. In standard experiments nitrogen was bubbled into the solution with the flow rate of $11 \mathrm{~L} / \mathrm{h}$. As reactions (Eqs. (2) and (3)) lead to the formation of 3 moles of $\mathrm{Cl}_{2}$ gas per 1 mole of decomposed chlorate, the nucleation of chlorine bubbles might be a rate limiting step of the whole process, which can be eliminated if nitrogen is bubbled through the solution. Therefore additional experiments were run when the nitrogen flow of the same flow rate was led above the solution and even when the nitrogen flow was absent. Although the conversion rate of chlorate somewhat decreased in both cases, this decrease was not significant. Further, the nitrogen flow rate was increased by about 5 times (to $50 \mathrm{~L} / \mathrm{h}$ ) while nitrogen was bubbled into the solution. Although this lead to some increase in the conversion rate of the chlorate, this effect was not significant, either. Therefore nucleation of the chlorine bubbles is not a rate limiting step of reactions (Eqs. (2) and (3)).

As will be shown below, the increase in the $\mathrm{NaCl}$ concentration significantly enhanced the conversion rate of chlorate decomposition. In some experiments additional $\mathrm{NaCl}$ was added to the saturated solution. It was found that increasing the amount of $\mathrm{NaCl}$ above its saturation limit did not influence the conversion of chlorate above the level reached using the saturation concentration of $\mathrm{NaCl}$ (see the last points in Fig. 3). Thus, the decomposition of chlorate is a homogeneous chemical reaction and the presence of a solid $\mathrm{NaCl}$ phase does not have any influence on it.

\subsection{The decomposition rate of chlorate as function of NaCl-content}

The primary results of the experiments are shown in Table 1. In Table 1 the measured concentrations of $\mathrm{NaClO}_{3}(\mathrm{~g} / \mathrm{L})$ are shown as function of time in the interval 0 .. $120 \mathrm{~min}$ at different $\mathrm{NaCl}$ contents in the interval $0 \ldots 330 \mathrm{~g} / \mathrm{L}$ at constant temperature of $90^{\circ} \mathrm{C}$, at constant $\mathrm{HCl}: \mathrm{NaClO}_{3}=6: 1 \mathrm{~mol} /$ mol ratio and at constant nitrogen flow of $11 \mathrm{~L} / \mathrm{h}$ (nitrogen is bubbled through the brine solution). In the second row of Table 1 the initial chloride ion content is calculated, supposing that both the $\mathrm{HCl}$ and $\mathrm{NaCl}$ molecules are fully dissociated. In the last line of Table 1 the conversion (\%) of chlorate is calculated after $120 \mathrm{~min}$ compared to its initial concentration. In Fig. 3 the conversion \% of the chlorate is shown as function of the $\mathrm{Cl}$-ion content of the solution. As follows from Fig. 3, all measured points are situated along an approximated straight line starting from the origo, at least until the saturation limit. Above the saturation limit the conversion becomes independent on the concentration.

Based on Table 1 and Fig. 3 it is evident that the chlorate conversion considerably increases with the increase in the $\mathrm{NaCl}$-content of the brine solution from $99 \mathrm{~g} / \mathrm{L}$ to its saturated value of about $270 \mathrm{~g} / \mathrm{L}$. Thus, from the technological

Table 1 Primary experimental results: measured $\mathrm{NaClO}_{3}$ concentrations in $\mathrm{g} / \mathrm{L}$ as function of reaction time at different $\mathrm{NaCl}$ contents at $90^{\circ} \mathrm{C}$ and $\mathrm{HCl}: \mathrm{NaClO}_{3}=6: 1 \mathrm{~mol} / \mathrm{mol}$ with nitrogen gas bubbled into the $250 \mathrm{~mL}$ solution with flow rate of $11 \mathrm{~L} /$ hour

\begin{tabular}{lcccccccc}
\hline $\mathrm{NaCl}, \mathrm{g} / \mathrm{L}$ & 0 & 99 & 200 & 240 & 255 & 270 & 284 & 330 \\
$\mathrm{Cl}-\mathrm{g} / \mathrm{L}$ & 37.2 & 92.9 & 157.0 & 183.9 & 194.0 & 202.7 & 212.8 & 241.1 \\
\hline $0 \mathrm{~min}$ & 18.6 & 16.4 & 17.8 & 19.1 & 19.6 & 19.4 & 20.2 & 20.4 \\
$10 \mathrm{~min}$ & 16.3 & 15.3 & 12.5 & 10.9 & 9.5 & 8.3 & 8.2 & 7.0 \\
$20 \mathrm{~min}$ & 16.2 & 14.7 & 11.5 & 9.2 & 8.0 & 6.9 & 7.1 & 5.9 \\
$30 \mathrm{~min}$ & 16.2 & 14.5 & 10.3 & 8.3 & 8.4 & 5.9 & 6.6 & 5.4 \\
$40 \mathrm{~min}$ & 16.1 & 13.6 & 9.9 & 7.8 & 6.8 & 5.7 & 6.2 & 5.1 \\
$50 \mathrm{~min}$ & 16.0 & 13.3 & 9.3 & 7.4 & 6.4 & 5.5 & 5.8 & 4.9 \\
$60 \mathrm{~min}$ & 15.6 & 13.1 & 9.1 & 7.1 & 6.2 & 5.2 & 5.5 & 4.7 \\
$90 \mathrm{~min}$ & 15.9 & 12.1 & 8.1 & 6.2 & 5.5 & 4.7 & 5.1 & 4.3 \\
$120 \mathrm{~min}$ & 15.8 & 11.3 & 7.8 & 5.9 & 5.0 & 4.2 & 4.7 & 4.1 \\
conversion, \% & 15.1 & 31.3 & 56.2 & 69.1 & 74.5 & 78.4 & 76.7 & 79.9 \\
\hline
\end{tabular}

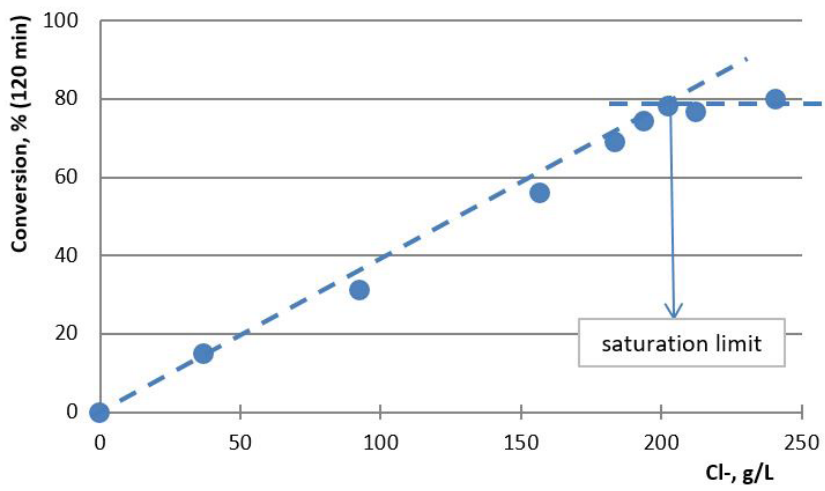

Fig. 3 Dependence of chlorate conversion on the chloride ion content of the solution, according to Table $1\left(90^{\circ} \mathrm{C}, \mathrm{HCl}: \mathrm{ClO}_{3}-=6: 1 \mathrm{~mol} / \mathrm{mol}\right.$, $\mathrm{N}_{2}$ flow $=11 \mathrm{~L} /$ hour, $250 \mathrm{~mL}$ of solution, measured after $120 \mathrm{~min}$, the last points are taken in over-saturated solutions) 
point of view Fig. 1 (b) is preferred in Fig. 1, i.e. the elimination of chlorate from the brine should be performed when the brine is saturated in $\mathrm{NaCl}$.

\section{Conclusions}

It is more reasonable in the chlor-alkali process first to re-saturate the brine by sodium chloride and only then to purify it from sodium chlorate by adding $\mathrm{HCl}$ before the solution is added into the electrolysis cell again (see Fig. 1(b)). This finding re-confirms the previous findings of Dotson et al [18, 20], but in this paper further experimental details are added (see Fig. 4).

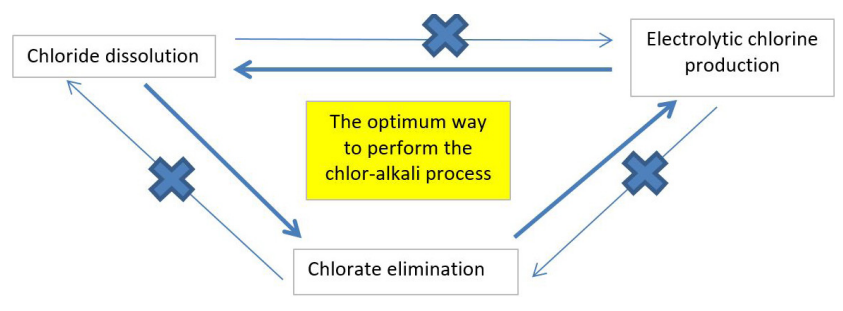

Fig. 4 Graphical abstract

\section{References}

[1] Perusich, S. A., Reddy, S. M. "Chlorate Transport through IonExchange Membranes", Journal of Applied Electrochemistry, 31(4), pp. 421-428, 2001.

https://doi.org/10.1023/A:1017511531847

[2] Paidar, M., Fateev, V., Bouzek, K. "Membrane electrolysisHistory, current status and perspective", Electrochimica Acta, 209, pp. 737-756, 2016.

https://doi.org/10.1016/j.electacta.2016.05.209

[3] Franco, F., Prior, J., Velizarov, S., Mendes, A. "A Systematic Performance History Analysis of a Chlor-Alkali Membrane Electrolyser under Industrial Operating Conditions", Applied Sciences, 9(2), Article Number: 284, 2019.

https://oi.org/10.3390/app9020284

[4] Westerhoff, P. "Reduction of Nitrate, Bromate and Chlorate by Zero Valent Iron (Fe0)", Journal of Environmental Engineering, 129(1), pp. 10-16, 2003.

https://doi.org/10.1061/(ASCE)0733-9372(2003)129:1(10)

[5] Srinivasan, R., Sorial, G., Sahle-Demessie, E. "Removal of Perchlorate and Chlorate in Aquatic Systems Using Integrated Technologies", Environmental Engineering Science, 26(11), pp. 1661-1671, 2009.

https://doi.org/10.1089/ees.2009.0153

[6] Kuznetsova, L. I., Kuznetsova, L. I., Koscheev, S. V., Zaikovkskii, V. I., Lisitsyn, A. S., Kaprielova, K. M., Kirillova, N. V., Twardowski, Z. "Carbon-supported iridium catalyst for reduction of chlorate ions with hydrogen in concentrated solutions of sodium chloride", Applied Catalysis A: General, 427-428, pp. 8-15, 2012. https://doi.org/10.1016/j.apcata.2012.03.024

\section{Acknowledgement}

The work is supported by the GINOP-2.2.1.-15-2016-00005 project. The project is co-financed by the European Union and the European Regional Development Fund.

- Ethics: There are no ethical issues about this research, as it is done only on inorganic, not living objects.

- Data accessibility: All data are collected in Table 1 of this manuscript.

- Authors contributions: LF designed the study. AJN and DS carried out the measurements including analytical chemistry and collected the primary experimental data. DS designed Fig. 2. GK produced Figs. 1, 3 and 4 and wrote the manuscript. All authors gave final approval for publication.

- Conflict of interest: The authors declare no competing interest.

- Funding: Financial support came from the GINOP2.2.1-15-2016-00005 project.

[7] Schwarz, A. O., Urruita, H., Vidal, J. M., Pérez, N. "Chlorate reduction capacity and characterisation of chlorate reducing bacteria communities in sediments of the rio Cruces wetland in southern Chile", Water Research, 46(10), pp. 3283-3292, 2012.

https://doi.org/10.1016/j.watres.2012.03.046

[8] Guo, Y. W., Zhang, H., Zhu, Z. L. "Chlorate Removal by Calcined $\mathrm{Mg} / \mathrm{Fe} / \mathrm{Ce}$ Layered Double Hydroxides", Applied Mechanical and Materials, 737, pp. 537-540, 2015.

https://doi.org/10.4028/www.scientific.net/AMM.737.537

[9] Vanyorek, L., Bánhidi, O., Muránszky, G., Sikora, E., Prekob, Á., Boros, Z., Farkas, L., Viskolcz, B. "Chlorate Elimination by Catalytically Hydrogenation, Catalyst Development and Characterization", Catalysis Letters, 149(1), pp. 196-202, 2019. https://doi.org/10.1007/s10562-018-2602-2

[10] Hong, C. C., Lenzi, F., Rapson, W. H. "The kinetics and mechanism of the chloride-chlorate reaction", The Canadian Journal of Chemical Engineering, 45(6), pp. 349-355, 1967.

https://doi.org/10.1002/cjce.5450450605

[11] Ernst, W. R., Shoaei, M., Forney, L. J. "Selectivity of the chloride-chlorate reaction system in various reactor types", AIChE Journal, 34(11), pp. 1927-1930, 1988. https://doi.org/10.1002/aic.690341123

[12] Deshwal, B. J., Lee, H. K. "Manufacture of chlorine dioxide from sodium chlorate: state of the art", Journal of Industrial and Engineering Chemistry, 11(3), pp. 330-346, 2005.

[13] Qian, Y., Chen, Y., Jiang, Y., Zhang, L. "A clean production process of sodium chlorite from sodium chlorate", Journal of Cleaner Production, 15(10), pp. 920-926, 2007. https://doi.org/10.1016/j.jclepro.2004.07.008 
[14] Sant Anna, R. T. P., Santos, C. M. P., Silva, G. P., Ferreira, R. J. R., Oliveira, A. P., Côrtes, C. E. S., Faria, R. B. "Kinetics and mechanism of chlorate-chloride reaction", Journal of the Brazilian Chemical Society, 23(8), pp. 1543-1550, 2012. https://doi.org/10.1590/S0103-50532012005000017

[15] Li, X. J., Jiang, D. D., Zhang, Y. J. "Kinetics of the Reaction for Generation of Chlorine Dioxide from Sodium Chlorate and Hydrochloric Acid", Advanced Materials Research, 634-638, pp. 546-550, 2013. https://doi.org/10.4028/www.scientific.net/AMR.634-638.546

[16] Karlsson, R. K. B., Cornell, A. "Selectivity between Oxygen and Chlorine Evolution in the Chlor-Alkali and Chlorate Processes", Chemical Reviews, 116(5), pp. 2982-3028, 2016. https://doi.org/10.1021/acs.chemrev.5b00389

[17] Endrődi, B., Simic, N., Wildlock, M., Cornell, A. "A review of chromium(VI) use in chlorate electrolysis: Functions, challenges and suggested alternatives", Electrochimica Acta, 234, pp. 108-122, 2017. https://doi.org/10.1016/j.electacta.2017.02.150

[18] Dotson, R. L. "Kinetics and mechanism for the thermal decomposition of chlorate ions in brine acidified with hydrochloric acid", Journal of Applied Chemistry and Biotechnology, 25(6), pp. 461-464, 1975. https://doi.org/10.1002/jctb.5020250608

[19] Lai, P., Szymanski, S., Christensen, N. L. "Removal of chlorate from electrolytic cell anolyte", Niagara Falls, NY, USA, US4169773A, 1979.

[20] Moore, S. H., Dotson, R. L. "Removal of chlorate from electrolyte cell brine", Munich, Germany, EP0098500A1, 1984.
[21] Reynolds, D. E., Kilby, J. D. "Process for removal of alkali metal chlorate from alkali metal chloride brines", Cheshire, CT, USA, US4609472A, 1986

[22] Okajima, K., Wakamatsu, H., Kumoi, S., Murakami, T. "Process for removing chlorate salt from aqueous alkali chloride solution", Munich, Germany, EP0488251B1, 1994.

[23] Huber, M. M., Korhonen, S., Ternes, T. A., von Gunten, U. "Oxidation of pharmaceuticals during water treatment with chlorine dioxide", Water Research, 39(15), pp. 3607-3617, 2005. https://doi.org/10.1016/j.watres.2005.05.040

[24] Kaur, D., Bhardwaj, N. K., Lochchab, R. K. "A study on pulping of rice stray and impact of incorporation of chlorine dioxide during bleaching on pulp properties and effluents characteristics", Journal of Cleaner Production, 170, pp. 174-182, 2018. https://doi.org/10.1016/j.jclepro.2017.09.111

[25] Gruchlik, Y., Linge, K., Joll, C. "Removal of organic micropollutants in waste stabilization ponds: A review", Journal of Environmental Management, 206, pp. 202-214, 2018. https://doi.org/10.1016/j.jenvman.2017.10.020

[26] Couri, D., Abdel-Rahman, M. S., Bull, R. J. "Toxicological effect of chlorine dioxide, chlorite and chlorate", Environmental Health Perspectives, 46, pp. 13-17, 1982. https://doi.org/10.1289/ehp.824613

[27] Li, Q. S., Cai, H. W., Li, G. X., Chen, G. Y., Ma, X. Y., He, W. L. "Degradation behavior of triclosan by co-exposure to chlorine dioxide and UV irradiation: influencing factors and toxicity changes", Environmental Science and Pollution Research, 25(10), pp. 9391-9401, 2018

https://doi.org/10.1007/s11356-018-1223-z 